\title{
Current Amendments Regulating ENFORCEMENT OF JUDGMENT IN \\ Upbringing OF Minors in SLOVAKIA
}

\author{
Svetlana Ficová ${ }^{1}$
}

\section{Faculty of Law, Komensky University in Bratislava, Slovakia email: Svetlana.Ficova@flaw.uniba.sk}

FICOVÁ, Svetlana. Current Amendments Regulating Enforcement of Judgment in Upbringing of Minors in Slovakia. International and Comparative Law Review, 2014, Vol. 14., No. 1, pp. 89-100. DOI: 10.1515/iclr-2016-0047.

\begin{abstract}
In her article the author deals with the amended provisions of the Code of Civil Procedure, effective as of 1 January 2012, governing the so called personal enforcement (enforcement of judgment in relation to the upbringing of minor children). In addition to the interpretation of the new statutory provisions, some reference is made also to various interpretation problems resulting from the new legal regulation, and some solutions of these problems are offered. Having analysed the more restrictive compulsory measures which may be ordered by the court against any person who has refused to comply voluntarily with the court decision concerning custody or visitation of a minor child or the decision relating to taking away a child, the author concludes that such measures may not always be effective.
\end{abstract}

Keywords: minor child, enforcement of judgment in cases of minor children, personal execution, taking away a child, parental visitation rights

\section{Introduction}

It was through the Act N. 338/2011 Coll. coming into effect on January 1, 2012 that the Civil Procedure Code, Act N. 99/1963 Coll. was amended (the Civil Procedure Code is further referred to as CPC). Apart from other things the amendment also covers the issues of personal enforcement of the court judgment. Ordinance N. 474/2011 Coll. defining the details of enforcement of judgment on upbringing of minors came into effect on the same day.

It should be said that the fundaments of the original legal regulation remained the same. There were only a few alterations made in reaction to the insufficiencies occurring in the enforcement of judgment on upbringing of minors as quoted by the press department of the Ministry of Justice in Slovakia ${ }^{2}$. These alterations

1 Associate profesor, Faculty of Law, Komensky University in Bratislava.

2 See more on http://aktualne.atlas.sk/na-sebeckych-rodicov-maju-sudy-a-policia-nove-paky/ 
specifically relate to the enforcement of judgment and the regulation covering visitation order with respect to a minor child. The insufficiencies consisted mainly in unclear definition of the court powers in enforcement of judgment on the upbringing of minors. Under the original regulation it was impossible to enter the abode where the child was detained unlawfully.

It is clear that the efficiency of these measures can only be tested after a longer period of time. However, it can now be said that it will not be possible to solve all the cases through the newly adopted regulation (e.g. the cases where the parties avoid the fulfilment of the obligations as ordered by the court in the judgment). Apart from that the adopted regulation shows signs of insufficiencies which could significantly obstruct the pursuit of justice.

The pursuit of justice can significantly be obstructed through the provision $\$ 272$ clause 2 of the Civil Procedure Code. Under this provision it is not the $\$ 251$ clause 4 of the Civil Procedure Code that can be applied to the enforcement of judgment on the upbringing of a minor. However, this provision is very important when talking about the enforcement of executive proceedings as it refers to the application of provisions in the preceding part of the Civil Procedure Code. It is logical that in cases of ruling out the application of the provision in the process of the enforcement of the judgment on upbringing of a minor there are aftereffects.

In fact the legal regulation dealing with the enforcement of judgment on the upbringing of a minor is very concise. The terms covered by this regulation are those such as request, fines, taking a child away, the enforcement of judgment, concurrence as well as delivering and local jurisdiction. Many other institutes or important issues are not covered at all.

Among those issues that are not covered at all the following can briefly be mentioned, such as e.g. the issue of what essentials are necessary in order to file the motion for the beginning of the enforcement of judgment or the issue of what the court procedure should be in cases when the motion for the enforcement of judgment does not have any prescribed essentials. The issue that is not covered either is e.g. the process of hearing, delivering the verdict and making a copy of this official document in a written form, remedial measures and so on. The area that is not covered no matter whether explicitly or based on some other provisions frequently referred to in this context is also the issue of certain specific conditions of action. It is necessary to realize that the enforcement of judgment on the upbringing of a minor is a proper civil procedure where it is essential that all the procedural steps have to be properly taken and all the requirements met at every stage of the action.

slovensko/spolocnost/ príspevok „Na sebeckých rodičov majú súdy a polícia nové páky“ as of 3.1.2012. 
The absence of a specific legal regulation of these issues related to the enforcement of judgment and at the same time the ruling out of reasonable application of the preceding parts would have negative impact on the execution of the rights to court protection if the law was supposed to be interpreted literally.

In such a case, there is no other possibility than to base the decision on the Slovak Constitutional Court ${ }^{3}$ ruling saying that in cases of the interpretation of regulation on the application of provisions and legal regulations it is essential that the literal meaning should primarily be taken into account. However, the court shall not be bound by the literal interpretation absolutely.

The court can do this and it could be said that there is in fact no other possibility in such cases when it is required for the purposes of the applicability of the law, the systematic continuance or if it is required in order to secure the harmony between the interpretation of Constitutional Court rulings and other general legally binding regulations (article 152 clause 4 of the Constitution). It is obvious that in such cases the court has to avoid making an arbitrary decision and it must base its interpretation of the legal norm on a rational argumentation.

Even under the ruling of the Czech Constitutional Court ${ }^{4}$ is it not admissible to base the application of the law solely on the literal language interpretation. Mechanical application of the law torn out of context, not taking into account its meaning and purpose of the law either intentionally or as a result of the lack of erudition of the professionals makes the law a tool of dissociation and absurdity.

Thus if we take into account all these facts there is no other possibility than to apply the provision $₫ 42$ clause 3 in combination with $₫ 79$ clause 1 of the CPC in connection with the essentials for the motion for the commencement of the proceedings. When talking about the form of the motion for the commencement of the proceedings it is necessary to apply the provision $₫ 42$ clause 1 of the CPC and as far as the court procedure in cases of lack of essentials it is necessary to apply $₫ 43$ clause 2 of the CPC.

Among all the requirements for the action as far as the enforcement of judgment is concerned the only legal regulation covering this area is the regulation dealing with jurisdiction and the participants of the proceedings.

The court that is under the provision of the $₫ 273$ clause 5 of the CPC defined as the court according to the local jurisdiction is the one that can be called as the general court of the minor. However, it is not further specified which court it is that can be called as the general court of the minor in the legal regulation covering the issue of the enforcement of judgment. Taking into account the fact that the provision $\$ 251$ clause 4 of the CPC is again disqualified through the $\$ 272$ clause 2 of the CPC it is only possible to solve the problem connected to the issue

3 The ruling filed under the mark III. Constitutional Court 2012/2011 the same ruling filed under the mark I. Constitutional Court 334/ 2011.

4 The ruling filed under the mark Pl. Constitutional Court 33/97. 
of which court will be the one to act in the local jurisdiction through following the rulings of the Constitutional Court in such cases. In such cases when the Constitutional Court ruling is supposed to be taken into account it is necessary to apply the provision $\$ 85$ clause 1 of the CPC, according to which the general court is the one in the jurisdiction where the minor has a place of residence, in cases when the minor does not have the place of residence then it is the court jurisdiction in the same area where the minor has whereabouts. It is also possible to apply the provision $\$ 11$ clause 3 of the CPC according to which it is the Supreme Court of the Slovak Republic which shall decide which court will deal with and decide the matter in such cases when the requirements of the local jurisdiction are not met or if it is not possible to find the required information.

In cases of the lack of the court jurisdiction this will also be solved through the ruling of the Constitutional Court based on the provision $₫ 105$ of the CPC.

The regulation covering the issue of the participants in the proceedings is not complete either. The provision $\$ 272$ clause 2 , the second section of the CPC merely says that the $\$ 94$ of the CPC can be applied. It means that in the enforcement of judgment on upbringing of a minor the group of participants is defined by third definition of the participants of the proceedings along with the regulation covering the issue how the court is going to proceed if the participants who are the part of the proceeding have not been dealt with yet or on the contrary if the participants who are not part of the proceeding have already been dealt with. However, in connection with the issue of participants in the proceedings there is no further regulation covering this area of law. This is for example the issue of how the court should proceed if e.g. the obligated party does not have the procedural capacity or how the court should proceed if the minor dies? The answer to this question that can be used for the purposes of court procedure can only be given when referring to the ruling of the Constitutional Court as mentioned above. It means that in cases when participant in the proceeding does not have the procedural capacity the court then has to discontinue the proceedings until a statutory representative has been officially established or the court can also use other measures that can be taken under the law. In the case of a death of a minor the proceeding shall be terminated as the death is regarded as a reason for discontinuance under the provision $\$ 107$ of the CPC as the enforcement regards the rights and duties of personal nature.

Even when trying to analyse other requirements for the proceedings (such as e.g. the absence of litispedence) it is necessary that the procedure enacted in the provision $\$ 103$ and subsequently in the CPC should be followed.

Among the institutes there is also one that should be briefly touched upon and it is the institute of the service of document. The only provision which mentions the service of the judgment during the enforcement of judgment on upbringing of a minor is the $\$ 273$ clause 6 of the CPC. However, this provi- 
sion relates solely to the service of a single procedural step taken by the court, namely the judgment on the taking away of the child. However, when analyzing this provision closely it can be said that it only regulates the issue of time when the service should be done. It does not cover the other related issues such as e.g. through whom it can be delivered, in what way, alternative service and the fiction of service. In spite of this it is important to apply general provisions about service enshrined in the provision $\$ 45$ and subsequently those in the CPC according to the ruling of the Constitutional Court.

After a short introduction focused on general issues the next part of this paper is limited to the explanation of the most important changes brought about by the current amendment. The list of the issues discussed further is as follows: the institute of notice, fine, the discontinuance of the payment of state welfare benefits, the taking away of the child, the discontinuance of the proceedings and the court costs.

\section{Notice}

The legal regulation is still centred on two phases of the enforcement of the judgment - the phase before the court order and the phase after the court order stipulating the details of the enforcement of judgment.

In the first phase, i.e. before the court order to enforce the judgment, the notice of the compulsory participant is obligatory in cases when he or she refuses to subdue to the judgment ( $\$ 272$ clause 3 of the CPC). The notice can be carried out in three different ways:

a. in a written form. Based on the text of the law it is not clear that written form should have the nature of a judicial resolution. Thus it means that there is no way to defend against this form of notice.

b. in an oral form. The court can order the hearing if it seems to be an effective way for the court to secure the purpose of the notice. The provision $\$ 272$ clause 3 of the CPC gives a list of persons which can be summoned for such a hearing. This regulation can be generally considered as an exception to the rule that it is essential that all persons should be summoned for such a hearing. The notice can also be made as a

c. part of a written record made immediately before the ordering of the enforcement of judgment on taking away of the child, which shall be serviced along with the decision upon the taking away of the child.

It is purely upon the discretion of the court which option it will take. However, the facts that can be considered as the key ones are those that can be found out about the obligated party, their conduct, their reasons for which they refuse to subdue themselves to the enforcement based on which it can be presupposed which form of notice will be more effective or theoretically which form may 
obstruct the enforcement of judgment. When trying to find these facts the court can ask the authority focused on the social protection of the minor for assistance, it can also ask for help some other institutions or the municipal bodies.

Now matter which form of notice the court employs it always has to a) inform the obligated party that they have to comply with this requirement and b) warn the party against any potential sanctions in case of disobedience of the party as regulated in the execution title (the provision $\$ 272$ clause 3 of the CPC). According to the $\$ 3$ clause 1 of the ordinance No 474/2011 Coll. it means that it has to warn that there can be a fine imposed, even repeatedly, it also has to warn against the possible discontinuance of the payment of the parental welfare benefit and other payments supporting the child including allowance as a part of the payment supporting the minor. It also has to warn that it is essential to participate in the hearing, it has to warn against the crime of obstruction of the execution of official decision including the sanctions $(\$ 349$ of the Criminal Code) and then what should be viewed as the most effective measure against the obligated party the court should warn that it is possible to change the decision about the personal care under the $\$ 25$ clause 4 of the Family Code even without filing the motion to do so.

Imposing fines is not obligatory and so it is left solely upon the discretion of the court whether to use this type of enforcement of not. It is not bound to impose such a fine if it is clear that the fine will not be of any use, i.e. it will not have the desired effect (e.g. the person does not own a property that can be seized $)^{5}$, and the same applies to cases when it is likely that the repeated notice for a hearing could lead to a successful procedure.

The amount to be paid in one fine has been increased up to 200 euro. However, based on the provision $\$ 273$ clause 1 of the Civil Procedure Code it is clear that the fine that can be imposed can only be equal to the amount of 200 euro. The statement of the intent of the legislators is in conflict with the current law. In the statement the legislator intended to set a fine only in the maximal amount that can be imposed at one time. This legislation is also different from the preceding legal regulation.

Such a fine can also be imposed repeatedly. The whole amount that can be imposed in this way has not been specified nor has it been limited by any special provision or regulation.

Every fine imposed in this way must be imposed through a separate provision which must be serviced to all the participants of the hearing. In cases of enforcement of a contact than it is necessary to impose a fine for failing to comply with the decision of court stating that there is a special time limit which has been breached. Otherwise such a provision is not reviewable. ${ }^{6}$ It is possible

5 Handl, V., Rubeš, J.: Občanský soudní řád. Komentář. II. díl. Praha : Panorama 1985, s. 292.

6 Handl, V., Rubeš, J.: Občanský soudní řád. Komentár. II. díl. Praha : Panorama 1985, s. 292.

(c) Palacký University Olomouc, Czech Republic, 2014.

ISSN 1213-8770 (print), ISSN: 2464-6601 (online). 
to appeal against the decision to impose a fine; the competent ${ }^{76}$ person who can also appeal is also the participant to the hearing.

Such a fine does not have the nature of a procedural fine, which means it cannot later be forgiven.

\section{The discontinuance of the payment of the state social benefits}

The innovation brought about by the Amendment to the Civil Procedure Code effective from January 1, 2012 is the fact that it is possible to discontinue the payment of the parental allowance (Act N. 571/2009 Coll. upon the parental allowance), the child benefits and the special allowance to the child benefits (the At N. 600/2003 Coll. upon the child benefits). The discontinuance of the payment is carried out by the employment office dealing with the social affairs and the issues related to family matters according to the place of residence of the obligated party, i.e. the receiver of the specific state social benefit ( $\$ 5$ clause 1 of the Act N. 571/2009 Coll. upon the parental allowance or $\$ 6$ clause 1 of the Act N. 600/2003 Coll. upon the child benefit), based upon the written notice of the court serviced to the obligated party.

One of the deficiencies that can be found in the current legal regulation is the fact that it uses the expression 'notice' which seems to be unclear. No provision can be interpreted in such a way that this notice should be in the form of resolution. However, if it is not to be in the form of a resolution than it means that the obligated party cannot defend against such a notice as there are not procedural institutes that can be used in such a case.

Analyzing the legal regulation covering these issues it is not clear whether the court can issue a notice to discontinue the payment of some of the social benefits listed above or notice to discontinue all of them at one time, i.e. those that the obligated party receives.

Logical interpretation of the law suggests that if the notice of the court is enshrined in the $\$ 273$ clause 2 of the CPC just as the right of the court to do so and not as its duty than the court can discontinue the payment of all the state social benefits at one time based upon its own discretion or it can discontinue the payment alternatively, i.e. it can discontinue some of the benefits only. In cases when the court decides to discontinue the benefits alternatively the chronology of such discontinuances listed in the legal regulation is not important. However, based on the literal interpretation of the law it cannot be understood in such a way that the court could issue a notice merely ordering that the benefits should be lowered.

The expected efficiency of these measures currently adopted could, however, be questioned. There are two main reasons for this.

$7 \quad{ }^{6}$ See the reasoning of the ruling filed under the mark I. Constitutional Court 138/03 p. 2 
The first reason is the fact that this type of enforcement can only be used against obligated party which is the receiver of the state benefits listed above, i.e. against the parent who was by the decision of the court assigned the duty to look after the child and this parent refuses to allow the second parent to visit the child. It cannot be used against the parent who merely has the visitation rights and refuses to return the child to the first parent, i.e. the one who has been assigned the duty to look after the child. The same applies to cases of joint custody where this enforcement measure cannot be used. In such cases it is also just one parent who is entitled to parental allowance, the state child benefit or the special allowance added to the child benefit ( $\$ 2$ clause 5 of the Act N. 571/2009 Coll. upon the parental allowance, $\$ 2$ clause 2 and 4 of the Act N. 600/2003 Coll. upon the child benefit). It is a pity that there is no other enforcement tool that could be used in cases when the parent who merely has visitation rights refuses to return the child to the other parent.

The second reason that can be used is the fact that this enforcement tool recently adopted can only be considered as effective in cases of parents with a lower income. In cases of parents who are well off this enforcement measure would probably not be effective at all.

The court is, however, allowed to use this enforcement measure only after it has issued a notice which has not been complied with by the obligated party. In other words unless a notice has been issued for the obligated party to comply with the decision of the court it is not possible to discontinue the payment of the social state benefits ( $\$ 273$ clause 1 of the Civil Procedure Code). However, it is not necessary to impose a fine first. It is even possible for the court to discontinue the payment of the benefits along with imposing a fine at the same time as the law allows that both measures can be applied at the same time.

The law takes into account the fact that the payment of the state social benefits will be commenced after it has been discontinued. It is, however, conditioned by the obligated party's compulsory compliance with the execution title. Thus the fact that plays the role in such cases is the fact that the obligated party has compulsorily started to fulfil the conditions of the execution title. It is not required to prove that the obligated party will continue fulfilling the conditions compulsorily, it is merely enough to prove that the party has begun to fulfil the conditions, i.e. the party has allowed the other parent to visit the child in such a way that is stipulated in the execution title.

Along with the commencement of the payment of the state social benefits the Act N. 571/2009 Coll. upon the parental allowance or the Act N. 600/2003 Coll. upon the child benefits also allows to balance the discontinued payment if the conditions stipulated by the law have all been fulfilled.

In connection with the newly adopted enforcement measures it would be good to consider adopting certain rights of the court to apply some education- 
al measures which could be more effective when dealing with such cases. The Czech legal regulation could serve as a good source of inspiration as it allows the Czech courts to impose a duty upon the obligated party to participate in an outof-court settling or mediation procedure or in a family or other possible therapy for up to three months [ $\$ 273$ clause 2 letter a) of the Civil Procedure Code].

\section{Taking away of the child}

In cases when the preceding measures ordered by the court have not had the desired effect, the court shall order that the child should be taken away from the parent.

Under the law the court can only use this type of enforcement of the duty imposed in such cases when the preceding notice addressed to the obligated party has not been successful. The taking away of the child is not possible without preceding notice. It is important to say again that in order to eliminate the possibility that the enforcement of the judgment will be obstructed (e.g. in case someone may place the child in a different location, the place being unknown to the court) it is only possible to service the notice to comply with the judgment along with the decision to take the child away ( $\$ 272$ clause 4 of the Civil Procedure Code). Thus the obligated party learns about the enforcement of judgment before the act of taking the child away itself. It is not necessary to impose a fine before such a decision has been made.

The decision-making process during which it is considered whether the child should be taken away or not should be thoroughly weighed as it is the most radical step that can be taken in this procedure. This step is regulated under the $\$ 273$ clause 2 of the CPC (currently it is under the section 4)]. This careful consideration must take into account the possible negative impact of such a step taken in relation to a minor. Such a consideration must also be based upon the finding of the facts ${ }^{8}$ of the specific case.

The rights of the court in the act of taking the child away are more precise in comparison with the older legal regulation. The new legal regulation includes rights such as e.g. the right to give orders to the objects participating in the taking away of the child, the right to ask for an explanation from the objects that can contribute to the clearance of the circumstances important for the enforcement of the judgment, the right to give an order for anybody not to enter a certain area or location within a specific time period or not to stay in a specific area or not to leave a specific area as far as the right to secure the opening of an apartment or other space with the aim to enter the space and take the child away ( $\$ 273 \mathrm{aa}$ clause 1 to 3 of the $\mathrm{CPC}$ ).

8 Slovak Constitutional Court finding as of November 2, 2011 filed under the mark III. Constitutional Court 181/2011. 
The opening of a flat or an apartment is only possible if two conditions have been satisfied, namely:

a) based on the reasonable belief that the child is present at the apartment (or other type of location); This reasonable belief does not necessarily have to mean that the judge must have clear evidence that the child really is present at the specific place or location and so this evidence does not necessarily have to be proved;

b) if the person who has a right to dwell in the apartment or space does not respect the notice made by the judge issued with the aim to take the child away. It is not relevant whether the person who legally is allowed to dwell in the apartment or other space is at the same time the obligated party or any other person. This also applies to cases no matter whether the person who as a right to dwell in the apartment or the space is a private person or a legal person. The law uses the word 'notices' i.e. a word in the plural which means that there should have been at least two ${ }^{9}$ notices made before the actual opening of the apartment or another space by force with the aim to take the child away.

In the act of the carrying out of the taking away of the child the court is allowed to impose a procedural fine of up to the amount of 820 euro.

The judge is under the obligation to secure the opening of the apartment or the space through a specially designated person ( $\$ 8$ clause 1 of the ordinance N. $474 / 2011$ Coll.). After the act of taking away of the child has been completed the judge is obligated to secure the closing of the apartment or the space no matter whether the taking away of the child was successful or not.

\section{The termination of the enforcement of judgment}

Until December 31, 2011 it had not been possible for the court to terminate the enforcement of the judgment upon the upbringing of a minor or the contact with the minor as this area was covered by the provision $\$ 272$ clause 1 of the Civil Procedure Code. However, it has been allowed since January 1, 2012 as regulated by $\$ 268$ of the Civil Procedure Code as these two provisions do not mutually exclude themselves.

It should be widely accepted and welcome that it is possible to terminate the enforcement of judgment upon the upbringing of a minor. There may be different reasons - the competent authority may propose, the execution title is still not enforceable, the execution title has been cancelled, it has become ineffective (e.g. as a result of the renovation of the parental cohabitation or as a result of a decision upon the divorce) etc. and thus any further continuation of the enforcement of judgment would deny the fundamental principles of logic, law and rights to just and fair court protection.

9 Similar also the explanatory report to the Act. 388/2011 Coll. $\$ 273 \mathrm{aa}$, point 55. 
If the obligated party states that their reason for the termination of the enforcement of judgment under the $\$ 268$ clause 1 letter $b$ ) of the CPC is reversed decision which serves as the fundament for the enforcement of judgment it is then necessary to wait for the lawfulness of the decision issued in the hearing according to the third section of the CPC (compare also the decision published under the N. 9/1996), unless this is the type of decision preliminarily enforceable or unless the preliminary enforceability has been specifically stated ${ }^{10}$.

At the same time it is also important to say that it is not possible to postpone the enforcement of judgment upon the upbringing of a minor. It is not even the filing of a motion by the obligated party to supplement the evidence by a specialist in the field of psychology as far as it is good to hand the minor over to a legitimate person under the execution title without any negative impact upon the development ${ }^{11}$ of the child that could have an effect on the execution of the enforcement of the judgment as it is not possible to apply the provisions on the postponement of the execution of the enforcement of the judgment in these cases under the $\$ 266$ of the Civil Procedure Code $[\$ 272$ clause 1 of the CPC (currently the original $\$ 266$ regulating the postponement of the execution of the enforcement of judgment is cancelled - author's note)]. Thus the process of evidencing could only be carried out in the subsequent hearing initiated upon the motion to the change of the placement of a minor. ${ }^{12}$

The only exception to this rule is the enforcement of judgment of a foreign court the enforcement of which can be postponed by the local court if the decision had been challenged by a remedial measure in the foreign state in which it was issued ( $\$ 273 \mathrm{~b}$ clause 2 of the CPC). The postponement is only possible based upon a motion until a final decision about a remedial measure has been made.

\section{The Court Costs}

As regulated by the newly adopted legal regulation the court costs shall be paid by the obligated party ( $\$ 273$ clause 1 of the CPC). At this point it is good to point to the carelessness of the legislator using the term "bear" the court costs even though this term does not correspond with the legal terminology frequently used. In connection with the court costs the terms used in the Civil Procedure

10 See more R 21/ 1981, p. 521.

11 According to the facts of the case stated in the finding of the Constitutional Court, filed under the mark I. Constitutional Court 70/1998 (N. 12/1999) it is clear that "The mother had not seen her child from May 1996 and then subsequently in the act of enforcement of judgment on July 16, 1997 at the presence of the police officers, i.e. after more than a year, the child did not recognize the mother."

12 The regional court in Košice as an Appeal Court in the matter filed under the mark E 127/97 [used from the finding of the Constitutional Court filed under the mark I. Constitutional Court 70/1998 [N. 12/1999]. 
Code are either "to pay the court costs" ( $\$ 140$ and subsequently in the CPC) or the term "to cover the court costs" ( $\$ 142$ and subsequently in the CPC).

Court costs as a part of the enforcement of judgment are fully listed in the provision $₫ 273$ clause 2 of the CPC. These are namely:

- compensation for the lost wages of the individuals participating in the enforcement of judgment except for the wages of the obligated party

- costs related especially to the opening of an apartment or another space

- transportation costs paid for the participants of the hearing except for the transportation of the entitled person

- transportation costs paid for the transportation of the minor connected with the return of the minor in cases when the minor had been relocated unlawfully or arrested in accordance with the international treaties

- costs related to the essential needs of the child in the process of the enforcement of judgment (e.g. expenses paid for the baby car seat used when transporting the child, securing of clothes, medicine, nutrition etc. $\left.{ }^{13}\right)$.

It is obvious that these are costs burdening also the state during the process of the enforcement of judgment. In terms of legal terminology these are costs that have to be paid by the state. If it is subsequently the obligated party that is supposed to bear these costs than this is the same expression used for the covering of court costs. This means that the obligated party always has to compensate the state for the costs no matter whether the taking away of the child was successful or not.

The effort of the legislator to amend the legal regulation of the enforcement of judgment upon the upbringing of a minor is certainly widely accepted and welcome especially by those who have become personally involved in such cases. However, the procedural legal regulation still seems to be rather incomplete. At this point it is probably the legal regulation enacted under the $\$ 25$ clause 4 of the Family Code (Act N. 36/2005 Coll. of the Family Code) that can be seen as the most effective provision to be used in these cases. Under this provision the court is allowed to reverse a decision upon personal care even without a motion if one of the parents repeatedly, without any sound reason and intentionally does not allow the other parent to see the minor child as prescribed by the court in the verdict on the divorce. Being without one's child even for one day truly is one of the biggest pains a parent can ever experience ${ }^{14}$. In order to secure the voluntary fulfilment of duties in accordance with the execution title it would probably be enough if the public was aware of the fact that this provision has begun to be used more in practice.

13 Explanatory report to the Act N. 388/2011 Coll. Upon $₫ 273$ d, point 56.

14 See Durkovič, L. from the citizens' association The Fathers' League in the contribution „Na sebeckých rodičov majú súdy a polícia nové páky“ zo dňa 3.1.2012, dostupné na: http:// aktualne.atlas.sk/na-sebeckych-rodicov-maju-sudy-a-policia-nove-paky/slovensko/spolocnost/ 